\title{
Indirect Spectrofluorometric Determination of Enoxaparin Sodium in Pharmaceutical Formulation (Injection) by Ion Association Complex Formation with Acriflavine Dye
}

\author{
Elham S. Salih ${ }^{*}$; Mohamed Th. Aghwan ${ }^{2}$ \\ Department of Chemistry, College of Education for Pure Science, University of Mosul, Iraq. \\ Email: ${ }^{*}$ altalibee 59@yahoo.com, ${ }^{2}$ Mohamed.aghwan@gmail.com
}

(Received July 01, 2018; Accepted October 24, 2019; Available online June 01, 2020)

DOI: 10.33899/edusj.2019.125843.1001, @ 2020, College of Education for Pure Science, University of Mosul.

This is an open access article under the CC BY 4.0 license (http://creativecommons.org/licenses/by/4.0/).

\begin{abstract}
A simple, sensitive and selective spectrofluorometric method has been developed for the determination of enoxaparin sodium in bulk and dosage forms (injection). The method was based on the quantitative quenching effect of enoxaparin on the native fluorescence of acriflavine due to the formation of nonfluorescent supramolecular ion association complex between the studied drug and acriflavine dye in aqueous solution. The decrease of acriflavine fluorescence was observed at $506 \mathrm{~nm}$ after excitation at $402 \mathrm{~nm}$. The relationship between quenching fluorescence intensity and concentration of enoxaparin sodium was linear in the range $0.05-20 \mu \mathrm{g} / \mathrm{ml}$ and with correlation coefficient 0.9990 and with LOD and LOQ 0.011 and $0.035 \mu \mathrm{g} / \mathrm{ml}$ respectively. The average recovery was $100.51 \%$ and RSD is less than $3.23 \%$. The stoichiometry of enoxaparin to acriflavine was calculated a 1:4. The method was applied successfully to the determination of enoxaparin as injection formulation and the results were in a good agreement with certified value and standard addition procedure.
\end{abstract}

Keywords: Spectrofluorometry, Acriflavine dye, Enoxaparin sodium, Ion association complex.

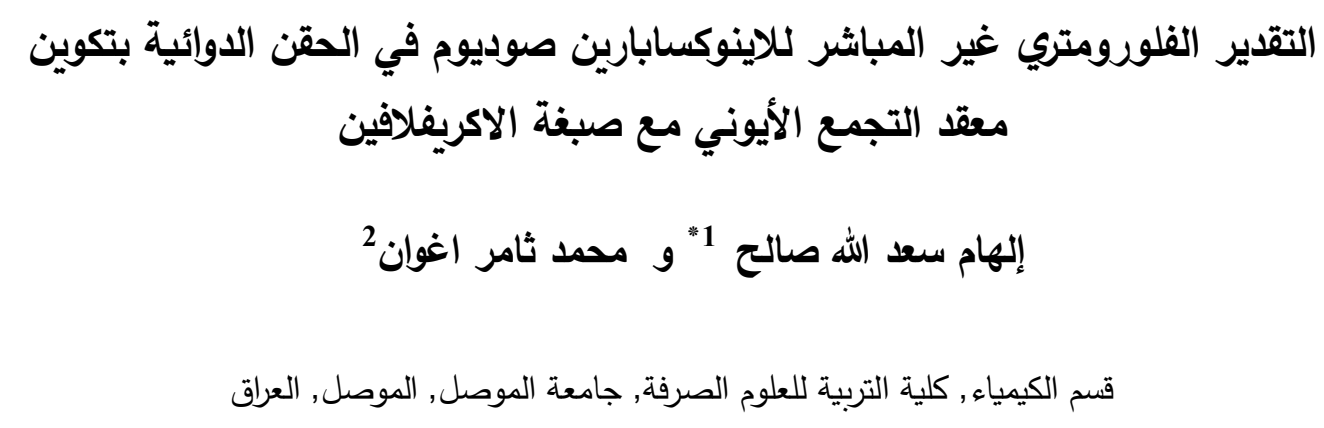

الخلاصة

تم تطوير طريقة فلورومترية يسيرة وحساسة وانتقائية لتقدير الاينوكسابارين صوديوم بثكله النقي وفي المستحضرات الدوائية

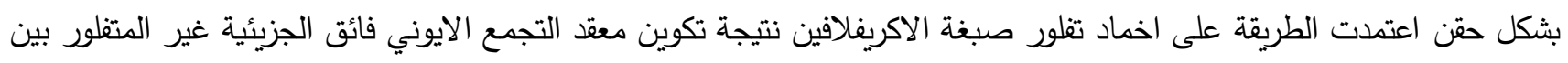

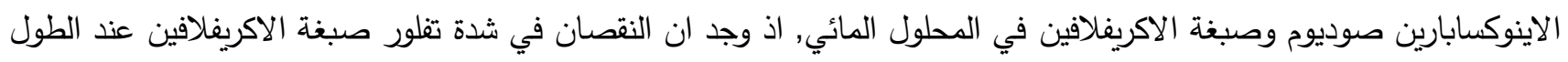

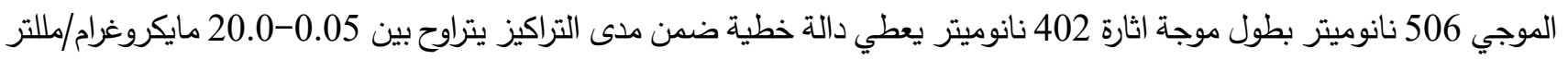

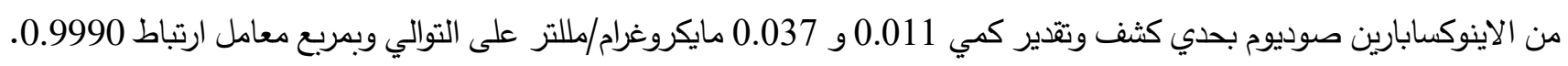


كانت الطريقة ذات دقة وتوافق جيدين, اذ تراوح معدل نسبة الاسترجاع 100.51\% وانحراف قياسي نسبي اقل من 3.23\% بلغت النسبة التركيبية المولية لطريقة نسبة الميل 4:1 (الاينوكسابارين صوديوم : صبغة الاكريفلافين). طبقت الطريقة بنجاح في تقدير

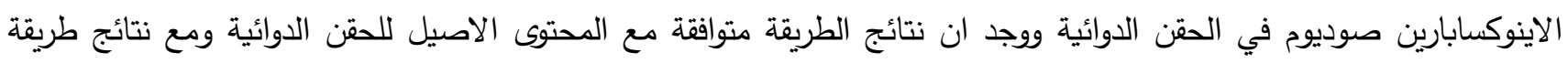

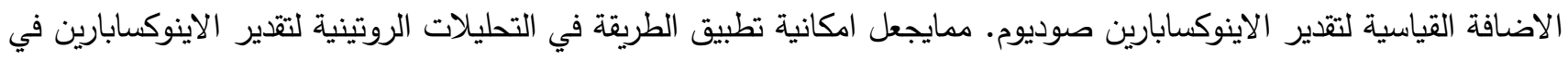
السوائل الحيوية

الكلمات المفتاحية: الفلورمتري وصبغة الاكريفلافين والاينوكسابارين صوديوم ومعقد التجمع الأيوني.

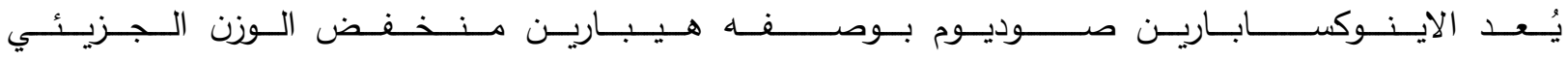

(Low-molecular weight heparin)

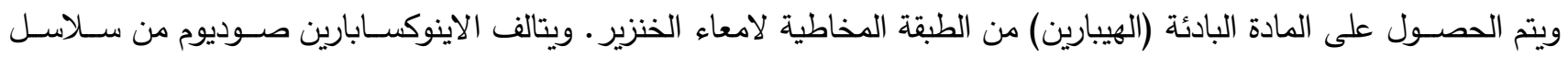

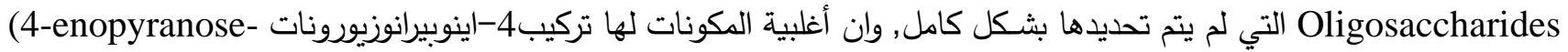
urinate) الوزن الجزيئي للاينوكســابارين صـــوديوم 4500 دالتون للمدى بين 3800 و 5000 دالتون[2] . يمتلك الاينوكســـابارين التركيب الكيميائي الاتي][1].

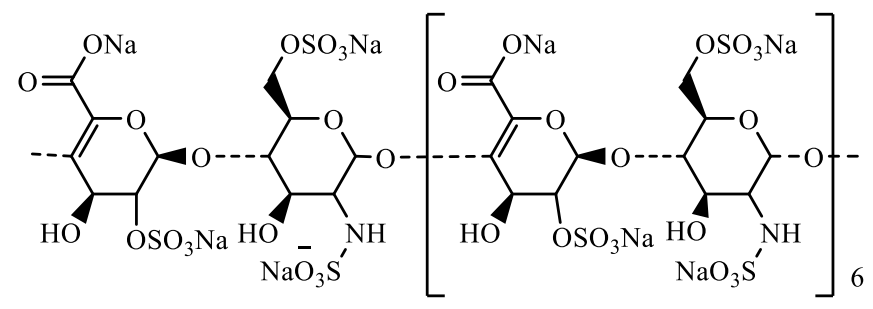

Enoxaparin sodium

Molar mass $=4645 \mathrm{~g} / \mathrm{mol}$

يوصف الاينوكسابارين للعلاج والوقاية من العديد من الاضطرابات السريرية وبضمنها الخثرة الدموية الوردية العميقة والاختلاج

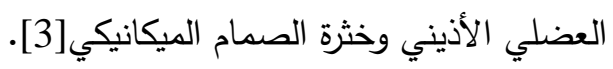

اقترحت طر ائق تحليلية مختلفة لتقدير الاينوكسابارين صوديوم اذوصفت المطيافية الفوتومترية الحالة الصلبة في تقدير العقار بهيئته النقية وفي الحقن الدوائية وذلك استتاداً إلى مبدأ قصـره كمياً لصبغة التولويدين الزرقاء (Toluidine-blue) [4]. واستعملت الصــبغة التفلورية هيبارين الحمراء في التقدير الحسـاس للاينوكسـابارين صـوديوم وذلك بالاعتماد على تأثيره في اخماد شـدة تفلور الصبغة[5]. كما تم تطبيق تسحيحات التجمع الايوني (ion association titration) في تقدير الاينوكسابارين صسوديوم (ويعرف

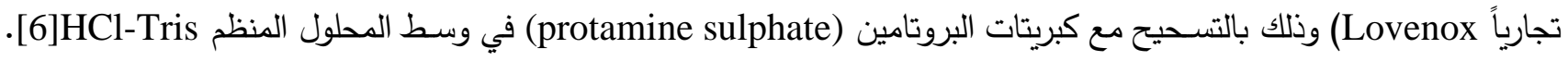

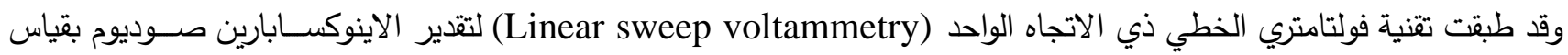
الموجة الكاثودية لصبغة لايت الخضـراء (Light green) في وسط محلول براتون - روبنسون المنظم (pH2.0) [7]. وامكن تحليل

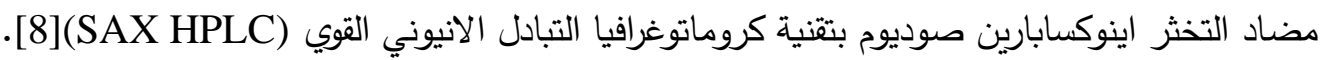


صبغة الاكريفلافين Acriflavine dye وتطبيقاتها التحليلية

تعد صبغة الاكريفلافين (AF) من مشتقات الاكريدين وغالباً ماتكون هيئتها التجارية عبارة عن خليط من 6,3-ثنائي -امينو -

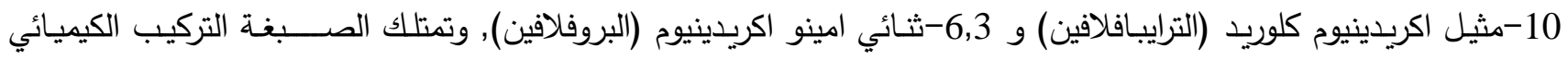<smiles>CN1C=c2cc3ccc(N)cc3nc2=Cc2ccc(N)cc21</smiles>

Acriflavine $\left(\mathrm{C}_{27} \mathrm{H}_{25} \mathrm{ClN}_{6}\right)$

Molar mass $=468.97 \mathrm{~g} / \mathrm{mol}$

ان الاكريفلافين عبارة عن مســـحوق برتقالي او بني اللون يذوب بالماء والكحول [10] ليعطي محلولاً اصـــفر او برتقالي

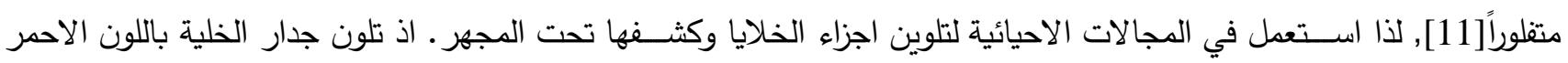
والنواة باللون الاصفر المخضر [12].

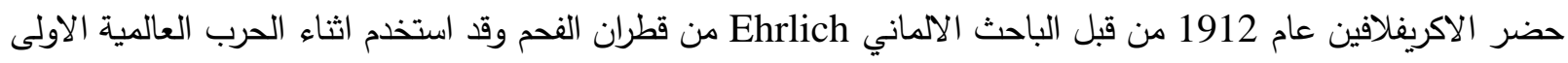
ضــ مرض النوم ومطهر موضـعي اذ عرف عن الاكريفلافين بانه له فعاليات قاتلة لطفيلي المثقبيات (Trypanocidal) ومضـــاداً للجراثيم والفايروسات[13]. واما تأثيراته على الخلايا السرطانية فقد عرفت منذ اكثر من 50 سنة. اذ يكون للاكريفلافين تأثير تثبيطي

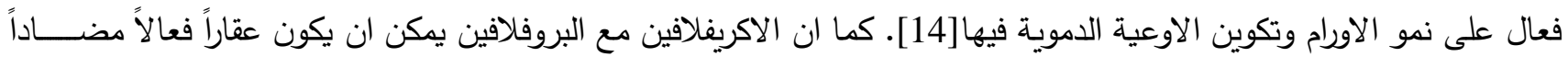
للملاريإن]

استخدمت صبغة الاكريفلافين في تطوير طرائق يسيرة عالية الحساسية لتقدير مركبات دوائية عديدة اعتماداً على مبدأ إخماد تفلور الصـبغة من خلال تكوين معقدات المزدوج الايوني غير المتفلور في وسط منظم بدالة حامضـية مناسبة, إذ وجد ان النقصـان

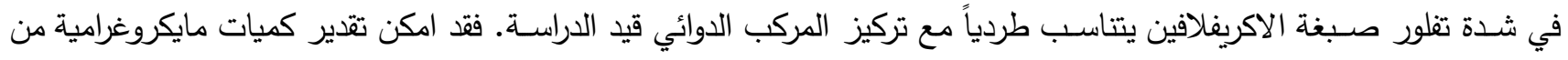

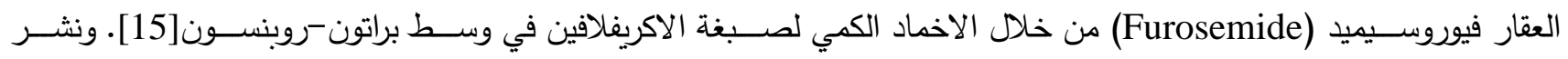
[16]Shenghui واخرون طريقة فلورومترية حسـاسـة لتقدير السـيفترياكسـون (Ceftriaxone) وذلك بتكوين معقد التجمع الايوني غير المتفلور بين المركب الدوائي وصــبغة الاكريفلافين. كما اســتخدمت الصــبغة في تقدير حامض الاسـكوبيك من خلال اخماد تفلورها[17].

ونظراً لقلة الطرائق التخصصسية لتقدير الاينوكسـابارين صـوديوم ولوفرة الصـبغة ورخص ثمنها, لذا يهدف البحث الى تطوير طريقة فلورومترية حســـــة لتقدير المركب الدوائي من خلال تكوين معقد التجمع الايوني المسـتقر والذائب في الماء بدون عمليات 


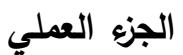

\section{الأجهزة المستعملة}

تم اجراء القياسات الفلورومترية باستخدام جهاز Shimadzu RF-5301 PC- Spectrofluorometer مجهز بمصباح الزينون (Xenon lamp) باستخدام خلايا الكوارتز شفافة من جميع الجهات ذات السك 1سم. وقيست الدالة الحامضية باستخدام جهاز الدالة الحامضية نوع Thermo RL 060P Electron Company-Singapore مرتبط بقطب مجهز من الشركة ذاتها.

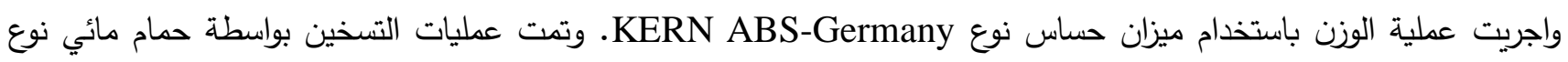

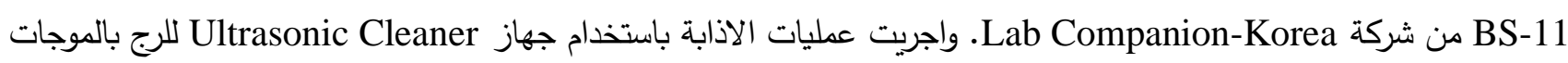
فوق الصوتية نوع Power Sonic 405 مجز من شركة Lab Tech-Korea.

\section{محاليل المواد المستعملة}

محلول الاينوكسابارين صوديوم (مجهز من شركة Sanofi) حضر محلول الاينوكسابارين بتركيز 100 مايكروغرام/مللتر وذلك

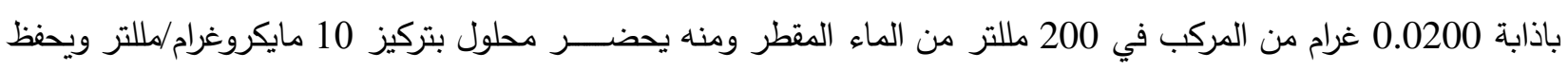
في الثلاجة ويبقى مستقراً لمدة اسبوع.

• محلول صبغة الاكريفلافين (شركة BHD) تم تحضير محلول الصبغة بتركيز 50 مايكروغرام/مللتر وذلك باذابة 0.0100 غرام

من الصبغة في الماء المقطر في قنينة حجمية سعة 200 مللتر ومنها تم تخفيف تركيز الصبغة الى 10 مايكروغرام/ملترك . محلول الفثالات المنظم (pH4.0) يحضر بمزج هيدروكسيد الصوديوم و فثالات الصوديوم الهيدروجينية كلاهما بتركيز 0.1

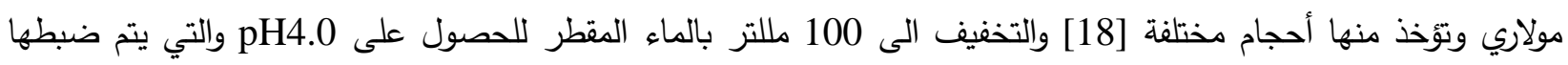
بوساطة جهاز قياس الدالة الحامضية. • محلول الخلات المنظم (pH4.0) يحضر بمزج حامض الخليك و خلات الصوديوم كلاهما بتركيز 0.2 مولاري وتؤخذ منها أحجام مختلفة [18] والتخفيف الى 100 ملتر بالماء المقطر للحصول على pH4.0 والتي يتم ضبطها بوساطة جهاز قياس

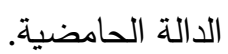
محلول براتون - روبنسون المنظم (pH4.0) يحضر بمزج حامض البوريك مع حامض الفنفوريك 85\% وحامض الخليك توخذ كميات مختلفة [18] يكمل الحجم بالماء المقطر في قنينة حجمية سـعة 1000 مللتر ويتم ضــبط الدالة الحامضـية باسـتخدام هيدروكسيد الصوديوم 0.2 مولاري. • محلول السترات المنظم (pH4.0) يحضر بمزج حامض الستريك و سترات الصوديوم كلاهما بتركيز 0.1 مولاري وتؤخذ منها أحجام مختلفة [18] والتخفيف الى 100 ملتر بالماء المقطر للحصول على pH4.0 والتي يتم ضبطها بوساطة جهاز قياس الدالة الحامضية. • محلول الفورمات المنظم (pH4.0) يحضـر بمزج هيدروكسيد الصـوديوم و حامض الفورميك كلاهما بتركيز 0.1 مولاري وتؤخذ منها احجام مختلفة [18] والتخفيف الى 100 مللتر بالماء المقطر للحصـول على pH4.0 والتي يتم ضــبطها بوسـاطة جهاز قياس الدالة الحامضية. • محاليل المتداخلات تحضر محاليل المتداخلات بتركيز 1000 مايكروغرام/ ملتر بإذابة 0.1000 غرام منها في 100 مللتر من الماء المقطر . 
• محاليل المواد الفعالة سطحياً تحضر محاليل المواد الفعالة سطحياً كل من SDS و و و CPCAB و بتركيز 0.1\% وذلك بإذابة

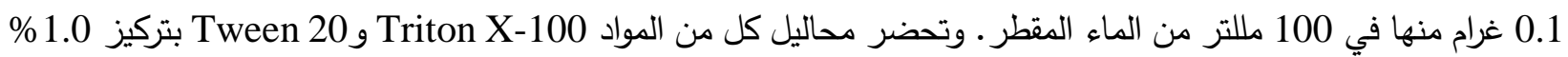
بإذابة غرام واحد منها في 100 مللتر من الماء المقطر. طريقة العمل وإلمنحنى القياسي

اضيفت الى مجموعة قنانٍ حجمية سعة 10 مللتر حجوم متزايدة (مللترات) من محلول الاينوكسابارين صوديوم بتراكيز 10 و100 مايكروغرام/مللتر لتغطية المدى الخطي 0.05-20 مايكروغرام/مللتر و1.7 ملتر من صبغة مانئ الاكريفلافين بتركيز 10 مايكروغرام/مللتر واكملت الحجوم بالماء المقطر الى حد العلامة وقيست شدة تفلورها (F) بعد 5 دقائق بدرجة حرارة الغرفة عند الطول

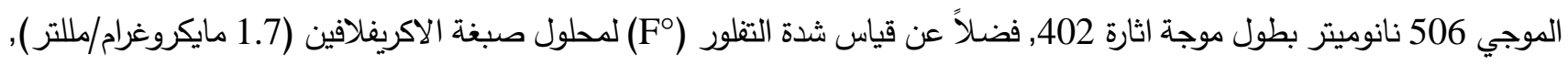

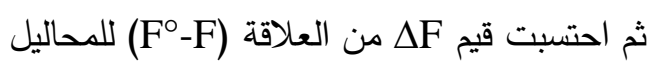

تحليل حقن الكليكسان والاينوكس

مزجت خمس حقن دوائية من كل مستحضر دوائي Clexane 4000anti-Xa IU/0.4ml من انتاج شركة Sanofi-aventis و Fnox 6000 anti-Xa IU/0.6ml من انتاج شركة Istanbul-Turkey ATABAY اذ تحتوي كل حقنة على 40 من 40 ملغم/0.4 مللتر او 60 ملغم/0.6 ملتر من الاينوكسابارين صوديوم وخفف 0.4 او 0.6 مللتر من محلول المزيج في قنينة حجمية سعة 100 ملتر بالماء المقطر لتحضير محلول بتركيز 400 مايكروغرام/مللتر لمستحضر الكليكسان و 600 مايكروغرام/مللتر لمستحضر الاينوكس, وحضر من كل منهما محلولين بتركيز 20 و50 مايكروغرام/مللتر وأخذت من المحاليل كميات مايكروغرامية من المركب الدوائي وعوملت على وفق طريقة العمل الموصوفة للمحاليل القياسية، وتم إيجاد التركيز من المنحني القياسي مني للاينوكسابارين صوديوم بصيغته النقية.

النتائج والمناقشة الاراسة التمهيدية وطيف تفلور صبغة الاكريفلافين بهدف امكانية تطوير طريقة تفلورية بسيطة وحساسـة وانتقائية لتقدير الاينوكسابارين صوديوم تمت دراسـة طيف تفلور محلول

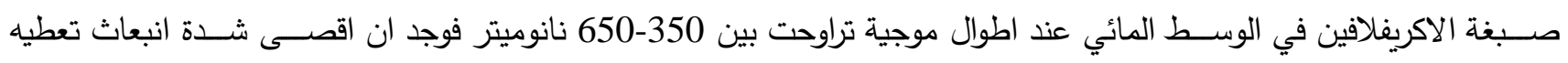
الصبغة كان عند الطول الموجي 506 نانوميتر بطول موجة اثارة 402 نانوميتر , الثكل 1. ووجد تجريبيا عند مفاعلة كميات مايكروغرامية من الاينوكسابارين في الوسط المائي مع صبغة الاكريفلافين حدوث اخماد خطي في

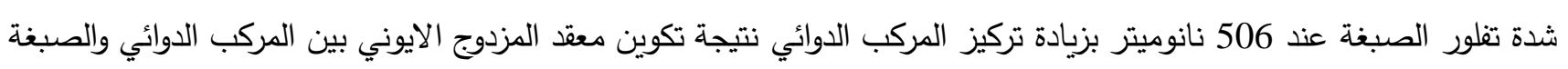
وهذا يؤكد امكانية استخدام الاكريفلافين كصبغة تفلورية في تقدير المركب الدوائي. 


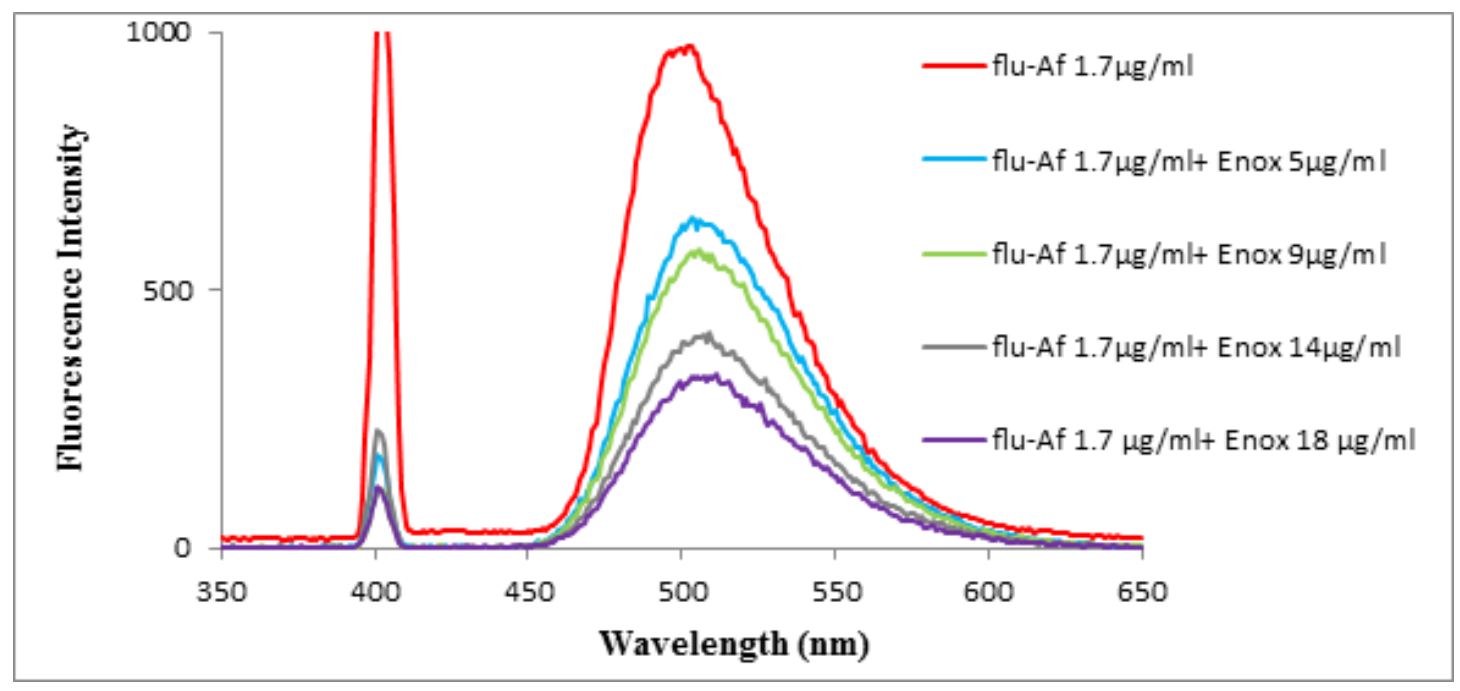

شكل 1: أطياف الاثارة والانبعاث لصبغة الاكريفلافين (1.7 مايكروغرام/ملتر) في المحلول المائي مقابل الماء المقطر وبوجود كميات مايكروغرامية من الاينوكسابارين صوديوم

ضبط الظروف المثلى

اجريت التجارب اللاحقة باستخدام 1.8 مللتر من محلول الاينوكسـابارين بتركيز 100 مايكروغرام/مللتر وإكمال الحجم بالماء المقطر في قنان حجمية سـعة 10 مللتر وقيســت شـــة تفلور الصــبغة عند الطول الموجي 506 نانوميتر بطول موجة اثارة 402 ن نانوميتر دراسة كمية صبغة الاكربفلافين

اجريت هذه الدراسة لتثبيت الكمية المثلى من صبغة الاكريفلافين التي يمكن استخدامها لتقدير الاينوكسابارين صوديوم والتي تقع ضـمن المدى الخطي للمنحنى القياسـي بين التركيز وشـدة التفلور , إذ تمت اضــافة حجوم متزايدة (0.1-2.0 مللتر) من من محلول صبغة الاكريفلافين بتركيز 10 مايكروغرام/ملتر واكمل الحجم بالماء المقطر الى حد العلامة وقيست شدة التفلور عند 506 نانوميتر

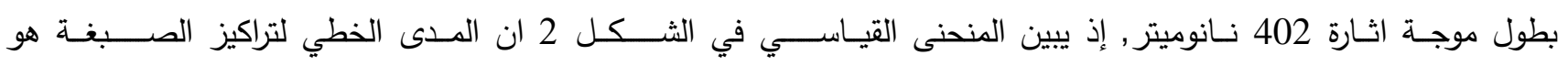
1.7-0.1 مايكروغرام/ملتر وعليه تم تتبيت التركيز 1.7 مايكروغرام/مللتر في الدراسات اللاحقة.

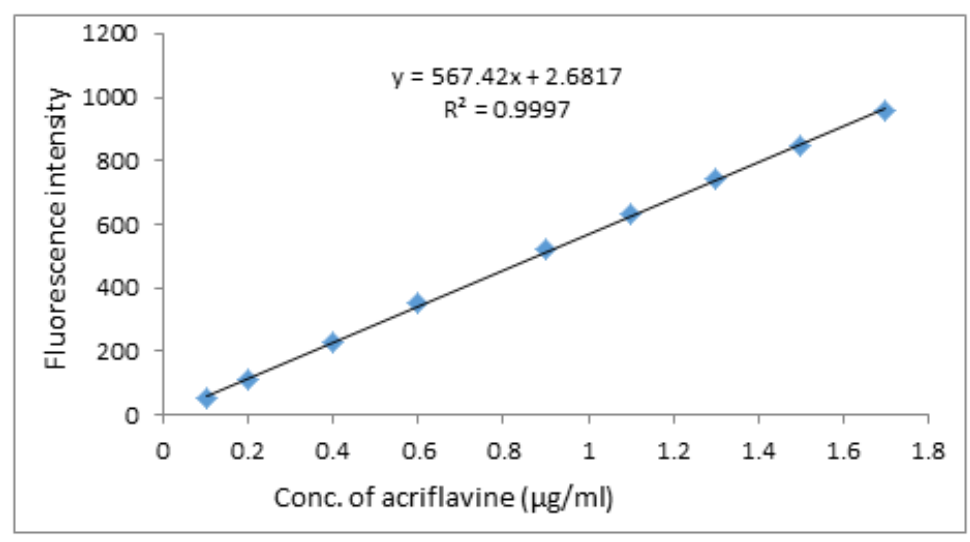

شكل 2: المنحنى القياسي لصبغة الاكريفلافين 
تاثير الدالة الحامضية والمحاليل المنظمة

لدراسة تأثير الدالة الحامضية في قيمة اخماد شدة تفلور صبغة الاكريفلافين عند تفاعلها مع المركب الدوائي فقد تم الاتي: اولاً تكوين معقد التجمع الايوني بين الصـبغة والاينوكسـابارين صـوديوم في المحلول المائي او بوجود محاليل محضـرة بدوال

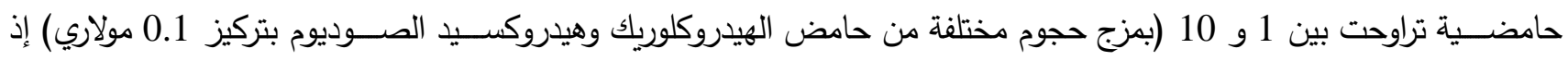

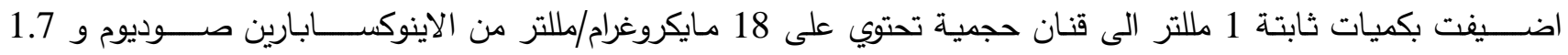

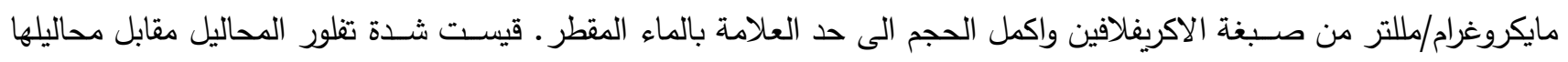

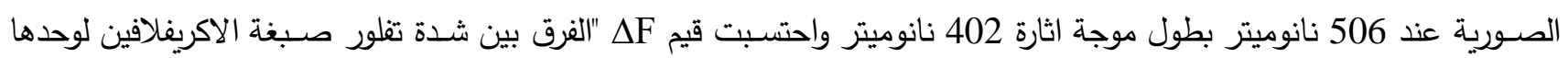

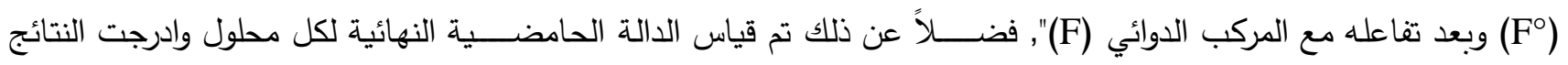
المستحصلة في الجدول 1.

جدول1: تاثير الدالة الحامضية في التقدير

\begin{tabular}{|c|c|c|c|c|c|c|}
\hline pH of solution added* & $\mathbf{F}^{\circ}$ & $\lambda_{\text {em }}$ & $\mathbf{F}$ & $\lambda_{\text {em }}$ & $\Delta \mathbf{F}^{*}$ & pH final \\
\hline 1 & 916 & 506 & 405 & 505 & 511 & 1.03 \\
\hline 2 & 956 & 508 & 467 & 509 & 489 & 2.06 \\
\hline 3 & 953 & 507 & 474 & 506 & 479 & 3.18 \\
\hline 4 & 964 & 508 & 476 & 508 & 488 & 4.34 \\
\hline 5 & 957 & 506 & 528 & 506 & 429 & 4.83 \\
\hline 6 & 921 & 509 & 550 & 508 & 371 & 5.92 \\
\hline 7 & 895 & 502 & 526 & 506 & 369 & 7.12 \\
\hline 8 & 847 & 506 & 486 & 504 & 361 & 8.61 \\
\hline 9 & 812 & 509 & 492 & 508 & 320 & 9.34 \\
\hline 10 & 776 & 508 & 448 & 508 & 318 & 9.81 \\
\hline With out & 965 & 506 & 341 & 506 & 624 & 4.1 \\
\hline
\end{tabular}

*1.0 ml buffer added

$* * \mathrm{~F}=\mathrm{F}^{\circ}-\mathrm{F}$

$\mathrm{F}^{\circ}$ : Intensity of $(1.7 \mu \mathrm{g} / \mathrm{ml})$ dye

$\mathrm{F}:$ Intensity of $(1.7 \mu \mathrm{g} / \mathrm{ml})$ dye $+(18 \mu \mathrm{g} / \mathrm{ml})$ enoxaparin sodium 
يلاحظ من النتائج المدرجة اعلاه تأثر قيم هF بتغير الدالة الحامضية, إذ وجد ان اعلى قيمة لـهF كانت عند إجراء التفاعل

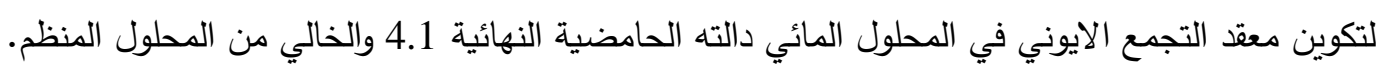
ثانياً حضـرت محاليل منظمة مختلفة بدالة حامضـية مقدارها 4.0 ودرس تأثير اضـافة 1.0 مللتر كلاً منها على حدى على

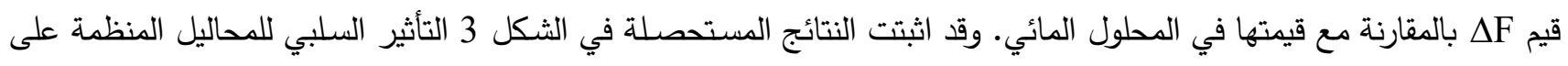
حساسية الطريقة, لذا استبعدت في التجارب اللاحقة واعتمد المحلول المائي وسطاً مناسباً لتقدير الاينوكسابارين صوديوم وباعلى قيمة

.$\Delta \mathrm{F} J$

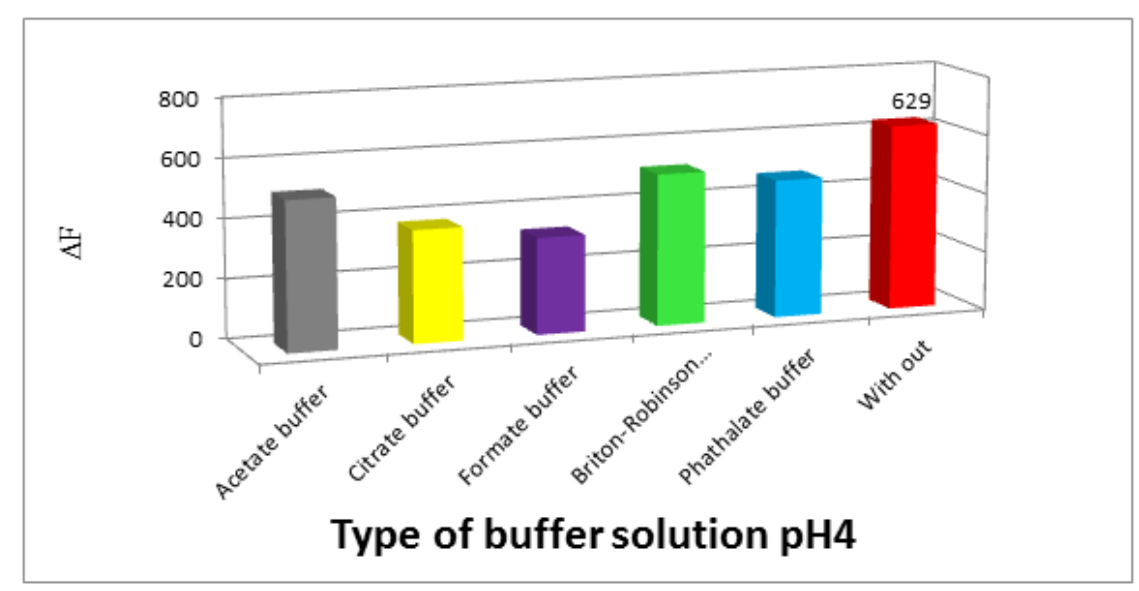

الثكل 3: تأثير المحاليل المنظمة بدالة حامضية 4 في تقدير الاينوكسابارين صوديوم

تأثير درجة الحرارة في زمن التفاعل واستقرارية صبغة الاكريفلافين

أجريت هذه الدراســــة لبيان تأثير درجات حرارية مختلقة (5-55॰ م) في زمن التفاعل وتكوين معقد التجمع الايوني بين

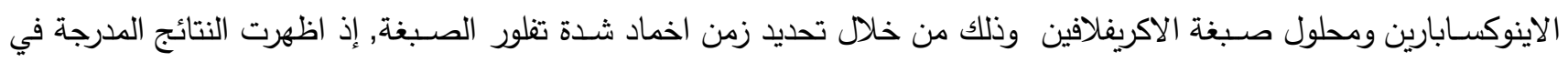

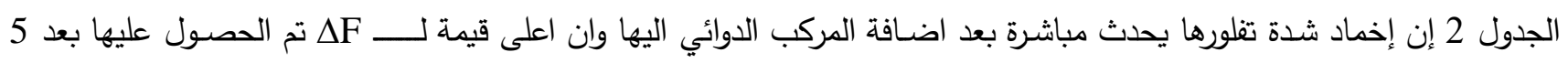

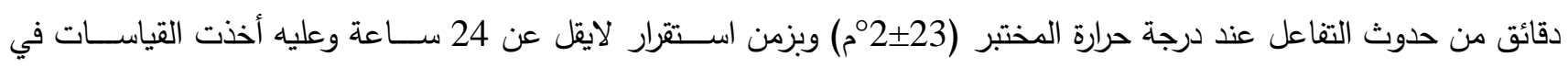
الدراسات اللاحقة بعد 5 دقائق من التخفيف الى حد دلى العلامة. 
Journal of Education and Science (ISSN 1812-125X), Vol: 29, No: 2, 2020 (45-62)

جدول 2: تاثير درجة الحرارة في زمن التفاعل واستقرارية صبغة الاكريفلافين

\begin{tabular}{|c|c|c|c|c|c|c|c|c|c|}
\hline \multirow{2}{*}{$\begin{array}{c}\text { Temp } \\
\left(\mathrm{C}^{\circ}\right)\end{array}$} & \multicolumn{9}{|c|}{$\Delta F /$ min standing time } \\
\hline & 5 & 10 & 20 & 30 & 40 & 50 & 60 & 120 & Over night \\
\hline 5 & 318 & 318 & 320 & 320 & 317 & 317 & 318 & 312 & -- \\
\hline R.T* & 625 & 625 & 624 & 624 & 625 & 623 & 623 & 623 & 619 \\
\hline 35 & 598 & 598 & 597 & 596 & 596 & 596 & 593 & 593 & -- \\
\hline 45 & 553 & 558 & 558 & 557 & 558 & 558 & 556 & 556 & -- \\
\hline 55 & 493 & 494 & 493 & 490 & 490 & 489 & 489 & 488 & -- \\
\hline
\end{tabular}

$* \mathrm{RT}=23 \pm 2{ }^{\circ} \mathrm{C}$

تأثير المواد الفعالة سطحيا

ان الهـف من هذه الدراسـة بيان مدى تأثيرها على شـدة تفلور صــبغة الاكريفلافين وقيم SF وذلك باضــافة 1.0 مللتر من

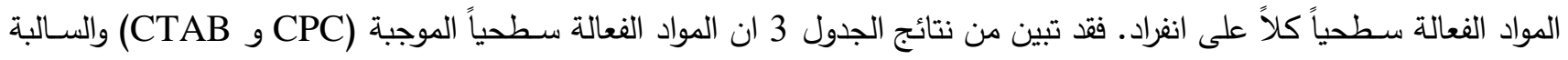
هF لها تأثير سلبي كبير على السبب الى تأينها وحدوث تجاذب (Interaction) مع المركب الدوائي ذا الثحنة

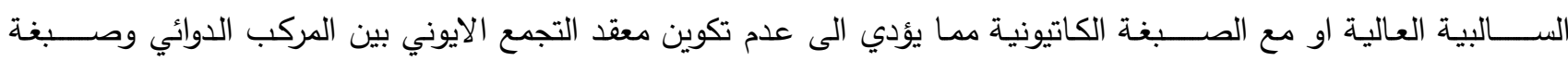

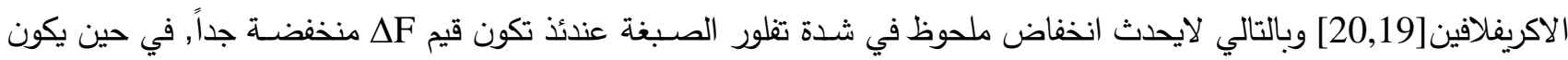

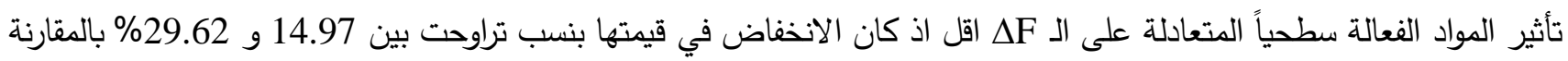
مع القيمة 628, وعليه استبعدت المواد الفعالة سطحياً في التجارب اللاحقة. الجدول3: تاثير المواد الفعالة سطحيا في تقدير الاينوكسابارين صوديوم

\begin{tabular}{|c|c|c|c|c|c|}
\hline \multirow{2}{*}{ Surfactant* } & \multicolumn{5}{|c|}{ Enoxaparin sodium } \\
\hline & $\lambda \operatorname{ex}(\mathrm{nm})$ & $\lambda \operatorname{em}(\mathrm{nm})$ & $\mathbf{F}^{\circ}$ & $\mathbf{F}$ & $\Delta \mathbf{F}$ \\
\hline SDS $0.1 \%$ & 403 & 510 & 980 & 973 & 7 \\
\hline СТАВ $0.1 \%$ & 403 & 505 & 971 & 960.7 & 10.3 \\
\hline СРC $0.1 \%$ & 407 & 514 & 948 & 943.9 & 4.1 \\
\hline Tween $800.1 \%$ & 402 & 503 & 935 & 401 & 534 \\
\hline Tween $200.1 \%$ & 402 & 503 & 941 & 499 & 442 \\
\hline Starch & 402 & 507 & 960 & 501 & 459 \\
\hline With out & 402 & 506 & 968 & 340 & 628 \\
\hline
\end{tabular}

* $1.0 \mathrm{ml}$ of surfactant 
تاثير المذيبات في شدة تفلور الاكريفلافين

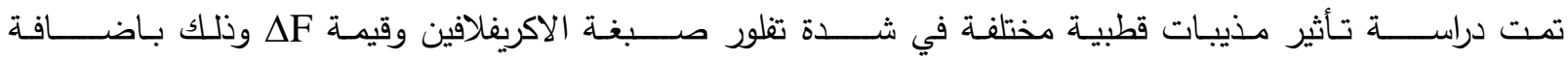

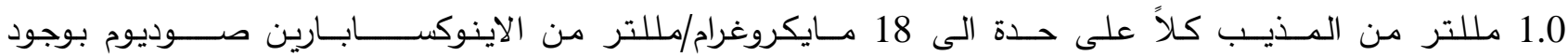
1.7 مايكروغرام/مللتر من الصبغة والتخفيف بالماء المقطر الى حد العلامة, إذ تشير النتائج المبينة في الجدول 4 ان الماء المقطر يعد وسطاً مناسباً للتفاعل إذ اعطى اعلى قيمة لـ

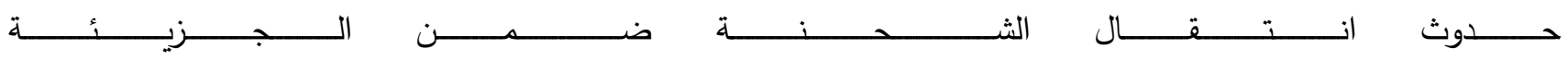
(Intramolecular charge transfer) مدى جهاز التفلور فضــــلاً عن حدوث إخماد خطي عند اضـــافة كميات مايكروغرامية من المركب الدوائي. في حين يظهر التأثير

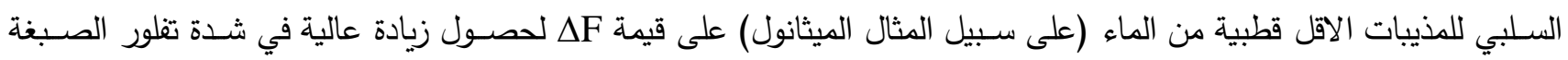

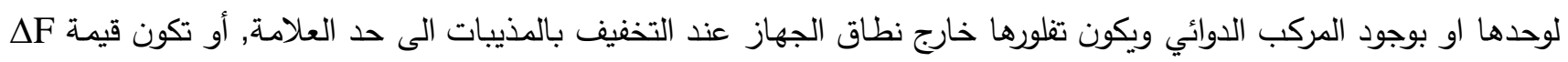
واطئة عند اضافة 1.0 مللتر من المذيبات لاحتمالية عدم تكون المعقد, وعليه استبعدت المذيبات في الدراسات اللاحقة, الثكل4. الجدول4: تأثير المذيبات

\begin{tabular}{|c|c|c|c|c|}
\hline Solvent* & Dielectric constant & $\lambda \operatorname{ex}(\mathrm{nm})$ & $\lambda \operatorname{em}(\mathrm{nm})$ & $\Delta \mathbf{F}$ \\
\hline Ethanol & 24.55 & 402 & 495 & 26 \\
\hline Methanol & 32.70 & 405 & 500 & 45 \\
\hline DMF & 36.71 & 404 & 502 & 49 \\
\hline Acetonitrile & 37.50 & 406 & 502 & 83 \\
\hline DMSO & 46.70 & 408 & 500 & 86 \\
\hline Water & 80.10 & 402 & 506 & 623 \\
\hline
\end{tabular}

* $1.0 \mathrm{ml}$ of solvent added 
Journal of Education and Science (ISSN 1812-125X), Vol: 29, No: 2, 2020 (45-62)

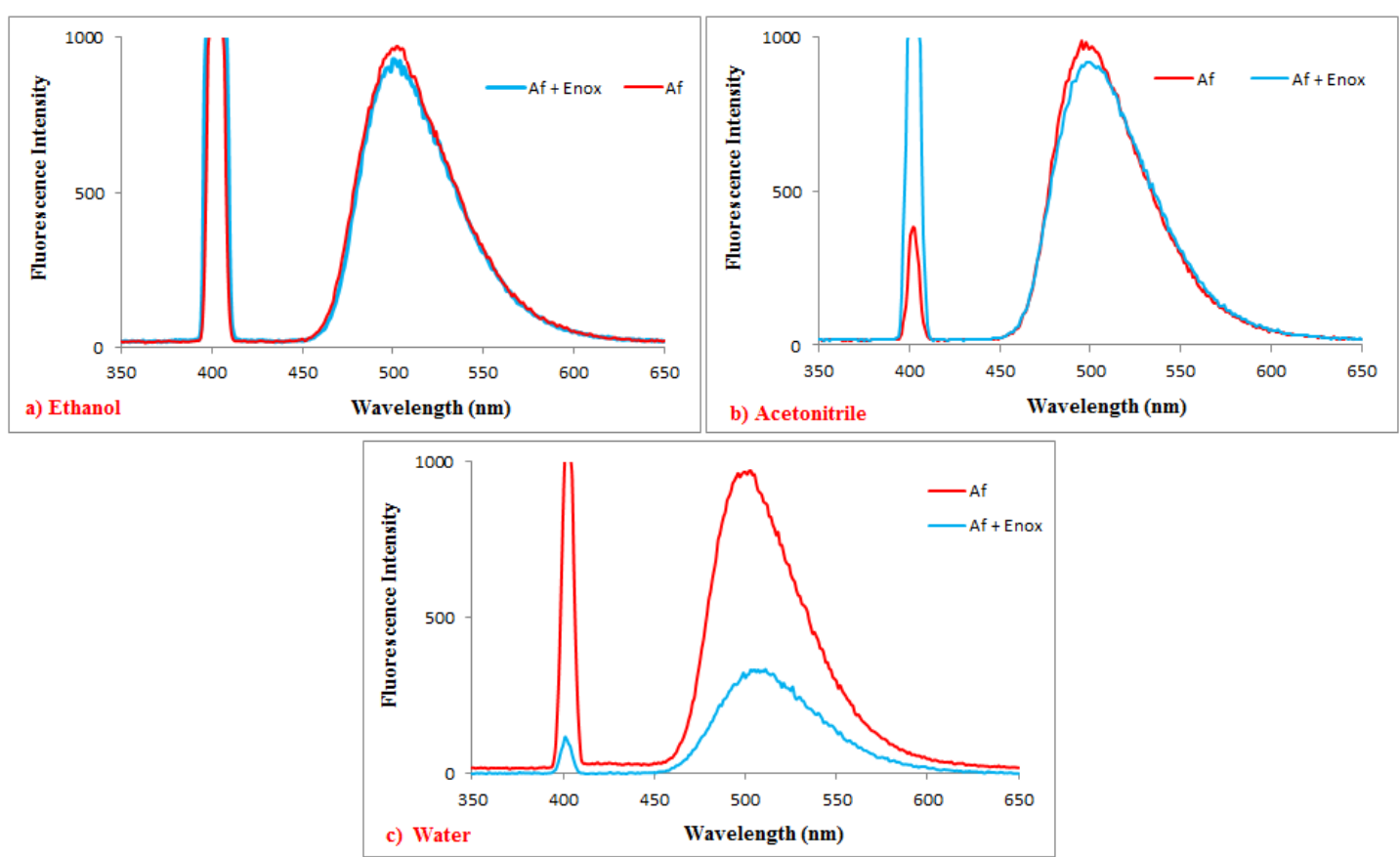

الثكل 4: اطياف الاثارة والانبعاث لصبغة الاكريفلافين (1.7 مايكروغرام/مللتر) بوجود 18 مايكروغرام/ملتر من الاينوكسابارين صوديوم و 1.0

القيم التحليلية الاحصائية للطريقة المقترحة

يبين الجدول 5 القيم التحليلية للمنحنى القياسي للاينوكسابارين صوديوم (الشكل 5)، فضلاً عن قيم حدود الكثف والتقدير الكمي التي تم حسابها بأخذ مكررات لاقل تركيز وقياس الانبعاث لها مقابل الماء المقطر وبتطبيق المعادلتين[22]:

$$
\mathrm{LOD}=\frac{3 \sigma \mathrm{C}_{\text {low }}}{\bar{X}} \quad \cdot \quad \mathrm{LOQ}=\frac{10 \sigma \mathrm{C}_{\text {low }}}{\bar{X}}
$$


Journal of Education and Science (ISSN 1812-125X), Vol: 29, No: 2, 2020 (45-62)

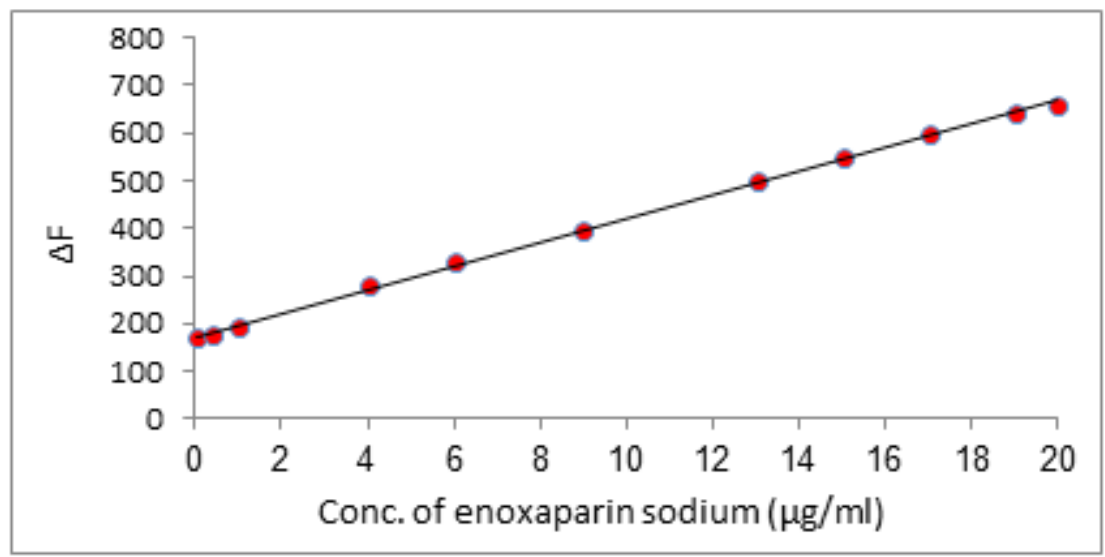

شكل 5: المنحنى القياسي لتقدير الاينوكسابارين صوديوم

جدول 5: القيم التحليلية للمعالجات الإحصائية للمنحنيات القياسية لتقدير الاينوكسابارين صوديوم

\begin{tabular}{|c|c|}
\hline Parameters & Enoxaparin sodium \\
\hline Linearity $(\boldsymbol{\mu g} / \mathbf{m l})$ & $0.05-20$ \\
\hline Intercept & 172.84 \\
\hline Slope & 24.789 \\
\hline Correlation coefficient & 0.999 \\
\hline Standard deviation of the intercept & 3.094 \\
\hline Standard deviation of the slope & 0.258 \\
\hline LOD* $(\boldsymbol{\mu g} / \mathbf{m l})$ & 0.011 \\
\hline LOQ $*(\boldsymbol{\mu g} / \mathbf{m l})$ & 0.037 \\
\hline
\end{tabular}

*Average of ten determinations of $\mathrm{C}_{\text {low }}$ of drug

دقة الطربقة وتوافقها

لمعرفة دقة الطريقة وتوافقها تم احتساب نسب الاسترجاع والانحراف القياسي لستة تراكيز مختلفة للاينوكسابارين صوديوم ضمن مدى المنحنى القياسي للتقدير. وقد استدل من نتائج الجدول 6 ان الطريقة ذات دقة جيدة وتوافق جيدين, إذ بلغ معدل نسبة

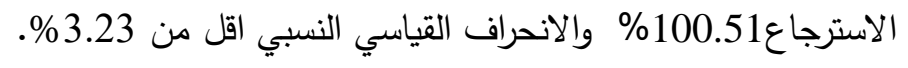


الجدول 6: دقة الطريقة وتوافقها لتقدير الاينوكسابارين صوديوم

\begin{tabular}{|c|c|c|c|c|}
\hline Drug & $\begin{array}{c}\text { Amount taken } \\
(\mu \mathrm{g} / \mathrm{ml})\end{array}$ & Recovery $(\%)$ & $\begin{array}{c}\text { Average } \\
\text { recovery }(\%)\end{array}$ & RSD* $(\%)$ \\
\hline \multirow{6}{*}{$\begin{array}{l}\text { Enoxaparin } \\
\text { Sodium }\end{array}$} & 0.4 & 102.46 & \multirow{6}{*}{100.51} & 0.77 \\
\hline & 1 & 97.46 & & 1.46 \\
\hline & 4 & 103.03 & & 3.23 \\
\hline & 8 & 99.42 & & 2.46 \\
\hline & 13 & 101.52 & & 1.09 \\
\hline & 19 & 99.18 & & 2.37 \\
\hline
\end{tabular}

*Average of six determinations

\section{دراسة طبيعة معقد التجمع الايوني المتكون}

تم دراسـة النسـبة المولية التركيبية لمعقد التجمع الايوني المتكون بين الاينوكسـابارين صـوديوم وصـبغة الاكريفلافين بتطبيق طريقة نسبة الميل, إذ تم تحضـير منحنيين قياسـيين من محلول المركب الدوائي والصـبغة محضـرين بتركيز 1×10-5 مولاري ليقاس شـدة التفلور عند 506 نانوميتر بطول موجة اثارة 402 نانوميتر حضـر الاول باضـافة حجم ثابت (4.0 مللتر) من محلول الصـبغة الى حجوم متزايدة (1.5-1.1 مللتر) من المركب الدوائي.

والثاني تم اضـــافة حجوم متزايدة من محلول الصـــبغة (0.1-1.5 مللتر) الى حجم ثابت (4.0 مللتر ) من المركب الدوائي. وتبين من الثكل (6) ونتائج قسمة ميل المنحنى الاول الى الثاني ان النسبة المولية للمعقد 4:1 (الاينوكسابارين: الاكريفلافين)
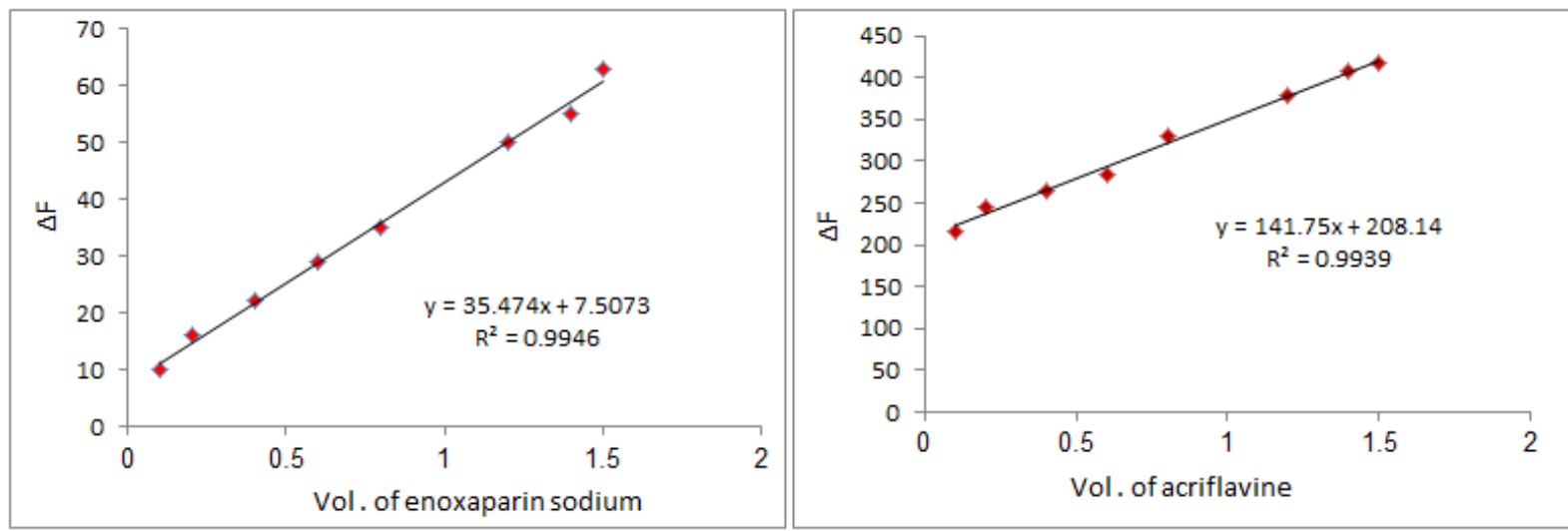

الثكل 6: نسبة الميل لتكوين المعقد بين الاينوكسابارين صوديوم والاكربفلافين 


\section{التفاعل الكيميائي المقترح}

يعد الاينوكسـابارين من السكريات المتعددة لعائلة كليكوزامينوكليكان المتكونة من وحدات السكريات الثنائية التي تحتوي على كلى

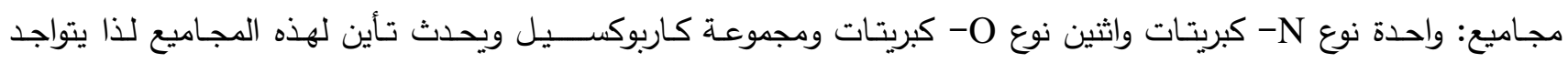

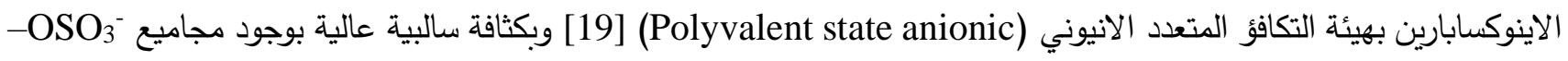

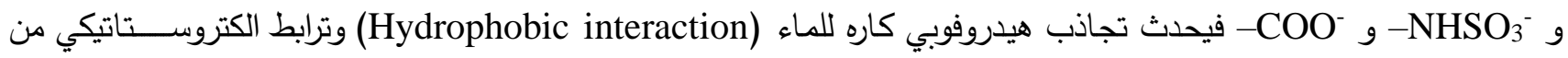
خلال ثلاث مجاميع من الكبريتات ومجموعة الكاربوكسيل مع مجموعة امينو الثالثية لثلاث جزيئات من الاكريفلافين الموجبة الثحنة مكوناً معقد التجمع الايوني فائق الجزيئية المتعادل غير المتفلور [5] (مخطط 1) وبنسبة مولية 4:1 (الاينوكسابارين : الاكريفلافين).

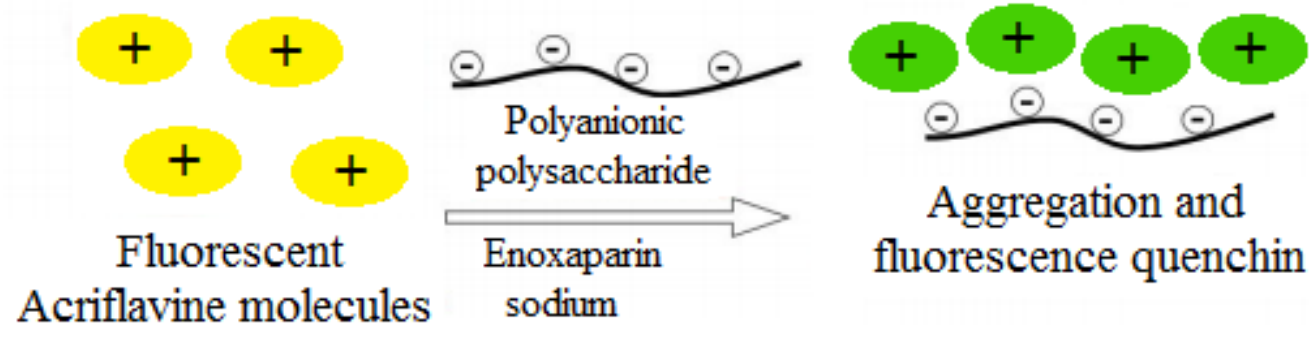

مخطط (1)

وبالاعتماد على نسبة الميل المستحصل عليها ادناه التفاعل الكيميائي المقترح لتكوين معقد التجمع الايوني (مخطط 2).

4<smiles></smiles>

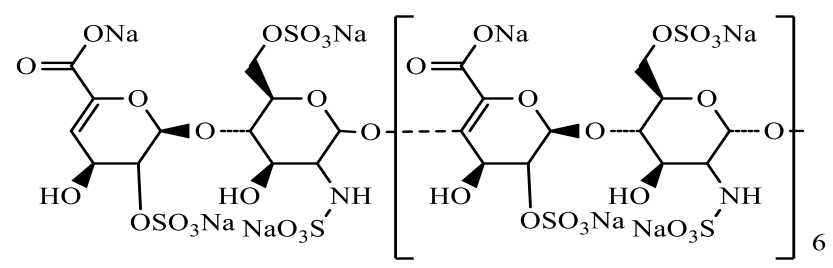
acetate $\mathrm{pH}=2.5$

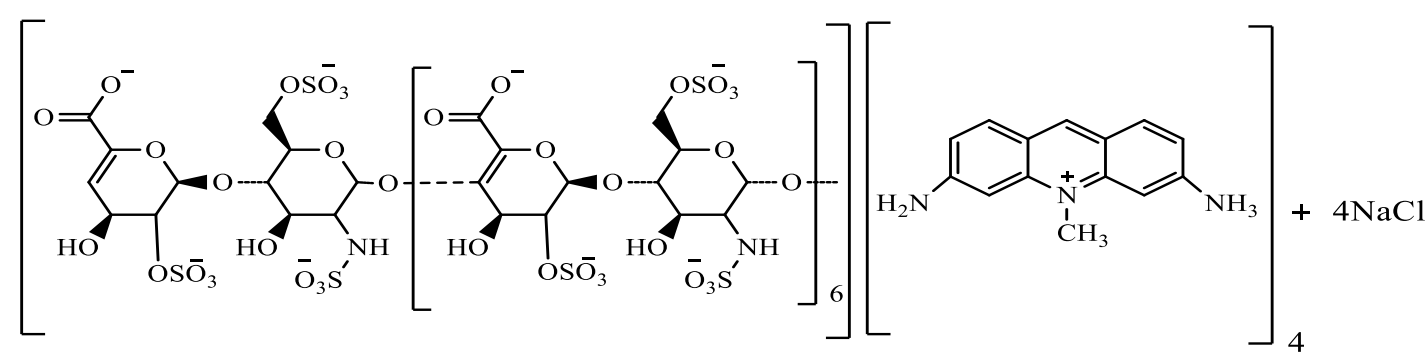

مخطط (2) التفاعل الكيميائي المقترح لتكوين معقد التجمع الايوني 
قبل تطبيق الطريقة على مستحضر الاينوكسابارين صوديوم وعلى السوائل الحيوية مستقبلاً, يجب التأكد من انتقائية الطريقة الفلورومترية وذلك بدراسـة تأثير السـكريات والاملاح والاحماض الامينية والبروتينات والايونات الفلزية وذلك باضـافة زيادة من هذه المواد انفرادياً الى 180 مايكروغرام/10 مللتر من الاينوكسـابارين صـوديوم. وقد تبين من النتائج المسـتحصــلة في الجدول 7 عدم حدوث تداخل يمكن ان تحدثه الجزيئات المتواجدة في الســـوائل والعينات الحيوية وهذا يعني امكانية تطبيق الطريقة في التحليلات

الجدول 7: تأثير المتداخلات في تقدير الاينوكسابارين صوديوم

\begin{tabular}{|c|c|c|c|}
\hline \multirow{2}{*}{ Foreign compound } & \multicolumn{3}{|c|}{ Recovery $(\%)$ of $180 \mu \mathrm{g}$ enoxaparin per $\mu \mathrm{g}$ of foreign compound added } \\
\hline & 100 & 250 & 500 \\
\hline Glucose & 101.30 & 101.71 & 102.37 \\
\hline Fructose & 98.57 & 101.30 & 102.70 \\
\hline Lactose & 99.07 & 99.48 & 100.19 \\
\hline Sucrose & 100.97 & 101.24 & 101.89 \\
\hline Glysine & 96.57 & 98.84 & 100.06 \\
\hline Cystine & 99.61 & 101.41 & 102.23 \\
\hline Cysteine & 101.61 & 102.16 & 102.54 \\
\hline Albumin & 101.17 & 102.67 & 104.60 \\
\hline L-glutamic acid & 100.82 & 101.46 & 101.93 \\
\hline L-glutamin & 101.72 & 102.31 & 102.71 \\
\hline L-theronine & 98.78 & 99.64 & 100.07 \\
\hline Pepsin & 102.18 & 102.63 & 103.03 \\
\hline Dopamine & 97.41 & 99.17 & 99.83 \\
\hline Adrenaline & 103.69 & 104.29 & 104.72 \\
\hline $\mathrm{NaCl}$ & 102.17 & 104.03 & 104.84 \\
\hline $\mathrm{KCl}$ & 101.18 & 102.63 & 103.74 \\
\hline $\mathrm{MgSO}_{4}$ & 100.04 & 100.79 & 102.10 \\
\hline $\mathrm{ZnSO}_{4} \cdot 6 \mathrm{H}_{2} \mathrm{O}$ & 97.37 & 98.22 & 99.59 \\
\hline
\end{tabular}




\section{تطبيق الطريقة المطورة في تقدير الاينوكسابارين صوديوم على الحقن الدوائية}

تم تطبيق الطريقة الطيفية المقترحة لتقدير المركب الدوائي قيد الدراسة على مستحضراته الصيدلانية ومن مناشئ مختلفة ودونت النتائج في الجدول 8 ويلاحظ الدقة العالية للطريقة المقترحة واتفاقها على نحو جيد مع المحتوى الأصيل للمركب الدوائي في مستحضراته

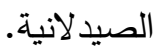

الجدول 8: تقدير الاينوكسابارين صوديوم في الحقن الدوائية

\begin{tabular}{|c|c|c|c|c|c|}
\hline $\begin{array}{c}\text { Pharmaceutical } \\
\text { preparation }\end{array}$ & $\begin{array}{c}\text { Certified } \\
\text { value }(\mathbf{m g})\end{array}$ & $\begin{array}{c}\text { Amount } \\
\text { taken } \\
(\mu \mathrm{g} / \mathrm{ml})\end{array}$ & $\begin{array}{l}\text { Drug content } \\
\text { found (mg) }\end{array}$ & Recovery* (\%) & $\begin{array}{c}\text { Average } \\
\text { recovery }(\%)\end{array}$ \\
\hline \multirow{5}{*}{$\begin{array}{c}\text { Clexane 4000anti-Xa } \\
\text { IU/0.4ml }\end{array}$} & \multirow{5}{*}{40} & 1 & 40.81 & 102.03 & \multirow{5}{*}{100.18} \\
\hline & & 4 & 39.40 & 98.50 & \\
\hline & & 8 & 39.55 & 98.88 & \\
\hline & & 14 & 40.37 & 100.93 & \\
\hline & & 18 & 40.22 & 100.55 & \\
\hline \multirow{5}{*}{$\begin{array}{c}\text { Enox } 6000 \text { anti-Xa } \\
\text { IU/0.6ml }\end{array}$} & \multirow{5}{*}{60} & 1 & 59.91 & 99.85 & \multirow{5}{*}{100.99} \\
\hline & & 4 & 62.85 & 104.75 & \\
\hline & & 8 & 59.85 & 99.75 & \\
\hline & & 14 & 60.72 & 101.20 & \\
\hline & & 18 & 59.63 & 99.38 & \\
\hline
\end{tabular}

*Average of four determinations

\section{المقارنة مع طريقة الاضافة القياسية}

لاثبات كفاءة الطريقة المقترحة وللتأكد من خلوها من المضـافات و لعدم توفر اجزة ومتطلبات الطريقة القياسية المذكورة في دستور الادوية البريطاني[23], فقد تم تطبيق طريقة الاضـافة القياسية على الحقن الدوائية للاينوكسـابارين صسوديوم اذ بينت النتائج الموضحة في الثكل7 والجدول9 ان طريقة الاضـافة القياسية متفقة بشكل جيد مع الطريقة المطورة المقترحة ضـمن المدى المقبول للخطأ (5 \%) مما يدل على ان الطريقة ذات انتقائية بشكل مرض. 


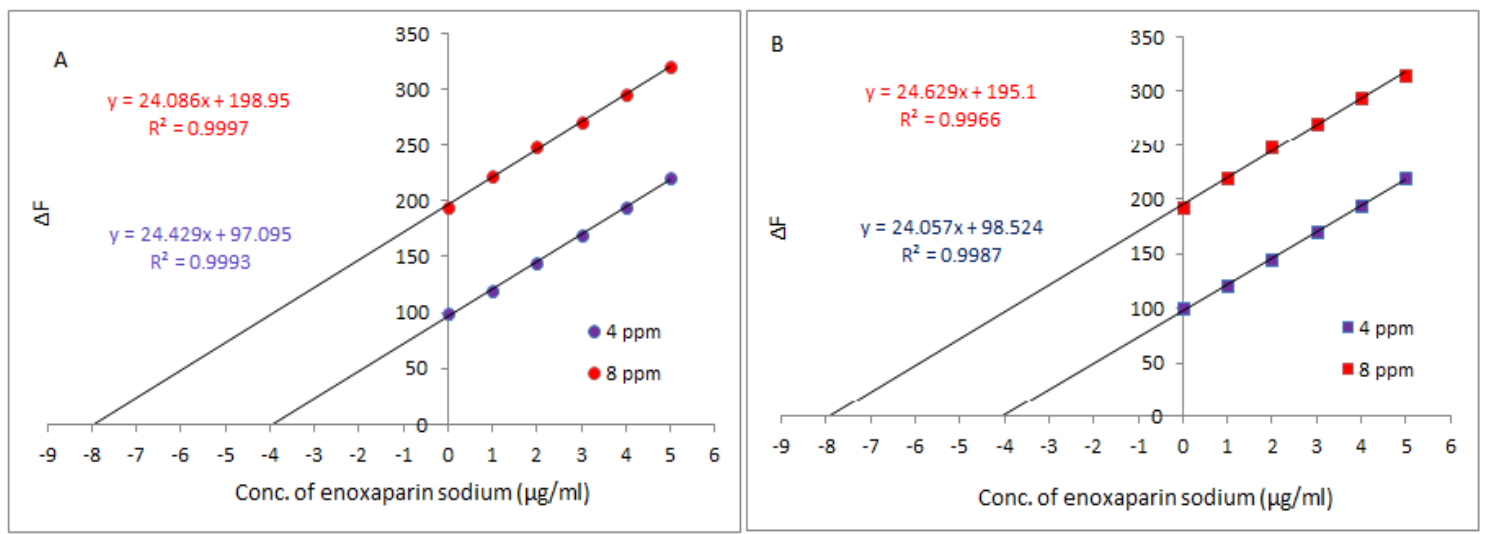

شكل 7: منحنيات الاضافة القياسية لتقدير الاينوكسابارين صوديوم A: كليكسان - فرنسي المنشأ B

الجدول 9: مقارنة الطريقة المقترحة لتقدير الاينوكسابارين صوديوم في الحقن الدوائية مع طريقة الاضافة القياسية

\begin{tabular}{|c|c|c|c|c|}
\hline \multirow{2}{*}{$\begin{array}{l}\text { Pharmaceutical } \\
\text { preparation }\end{array}$} & \multirow{2}{*}{$\begin{array}{c}\text { Certified value } \\
\text { (mg) }\end{array}$} & \multirow{2}{*}{$\begin{array}{l}\text { Amount taken } \\
(\mu \mathrm{g} / \mathrm{ml})\end{array}$} & \multicolumn{2}{|c|}{ Drug content found (mg) } \\
\hline & & & $\begin{array}{l}\text { Present } \\
\text { method* }\end{array}$ & $\begin{array}{c}\text { Standard addition } \\
\text { procedure }\end{array}$ \\
\hline \multirow{2}{*}{$\begin{array}{l}\text { Clexane 4000anti-Xa } \\
\text { IU/0.4ml France }\end{array}$} & \multirow{2}{*}{40} & 4 & 39.40 & 39.75 \\
\hline & & 8 & 39.55 & 41.30 \\
\hline \multirow{2}{*}{$\begin{array}{l}\text { Enox } 6000 \text { anti-Xa } \\
\text { IU/0.6ml Turkey }\end{array}$} & \multirow{2}{*}{60} & 4 & 62.85 & 61.43 \\
\hline & & 8 & 59.85 & 59.41 \\
\hline
\end{tabular}

*Average of four determinations

أقترحت طريقة تفلورية غير مباشرة سريعة وحساسة وانتقائية لتقدير الاينوكسابارين صوديوم من خلال تكوينه معقد المزدوج الأيوني الفائق الجزيئية مع الاكريفلافين بوصفه صبغة تفلورية في المحلول المائي وبدرجة حرارة الغرفة والذي يؤدي الى اخماد كمي

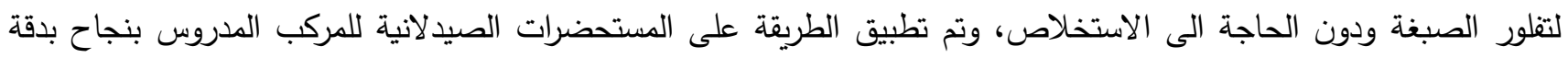
وتوفق جيدين ونتائج متفقة احصائياً مع طريقة الإضافة القياسية والمحتوى الأصيل للحقن الدوائية وبدون تداخل مما يجعل امكانية استعمال الطريقة في التحليلات الروتينية لتقدير الاينوكسابارين في السوائل الحيوية. 
1. The United States Pharmacopoeia, (2007) $30^{\text {th }}$ Revision, U. S. Pharmacopoeial Convention, Int., Rockville, MD.

2. Amold K. M., Capuzzi S. J. and Xu Y., Pharmaceuticals, 10, 1-15. (2017).

3. Costa R., Ferreira I. and Pedroso A., Eur. J. Case Rep. Intern. Med., 5, 1-4. (2018).

4. Gavrilenko M. A. and Gavrilenko N. A., Mendeleev Commun, 27, 419-420. (2017).

5. Warttinger U., Giese C. and Krämer R., https://arxiv.org/abs/1712.03377. (2017).

6. Qin W., Zhang W. and Xiao K. P., Anal. Bioanal. Chem., 377, 929-936. (2003).

7. Sun W., Ding Y. and Wang Q., Electroanal., 18, 1114-1120. (2006).

8. Sadowski R., Gadzala- Kopciuch R. and Kowalkowski T., J. AOAC Int., 100, 1706-1714. (2017).

9. Zargar P., Ghani E., Mashayekhi F. J., Ramezani A. and Eftekhar E., Oncol. Lett., 15, 1008410090. (2018).

10. Dana S., Dar A. and Dhar S. K., ACS Chem. Biol., 9, 2366-2373. (2014).

11. Jawad Y. M., Hamad H. T. and Al-Ragehey A. S. J. M., J. Coll. Basic Educ., 21, 197-204. (2015).

12. Duan Y., Sen B., Xie N., Paterson J. S., Chen Z. and Wang G., Microbes Environ., 33, 195204. (2018).

13. Lateef S. M., Awad M. A. and Abdul Hameed H. H., J. Global Pharm. Tech., 10, 455-461. (2018).

14. Lee C. J., Yue C. H., Lin Y. J., Lin Y. Y., Kao S. H., liu J. Y. and Chen Y. H., Anticancer Res., 34, 6467-6472. (2014).

15. Qader A. F., and Fakhre N. A., 6 ${ }^{\text {th }}$ Int. Conf. Workshops Basic Appl. Sci., (2017).

16. Shenghui F., Jian L. and Shaopu L., Chem. Res. Appl., 22, 1170-1773. (In Chinese). (2010).

17. Ali L. I. A., Qader A. F., Salih M. I. and Aboul-Enein H. Y., Luminescence, 34, 168174.(2019).

18. Perrin D. D. and Dempsey B., "Buffer for $\mathrm{pH}$ metal ion control", Chapman and Hall Ltd., London, (1974), p. 128-139.

19. Sun W., Hang J-Y. and Jaio K., S. Afr. J. Chem., 60, 42-46.(2007)

20. Hui N., Sun W. and Ding Y-Q, J. Chinese Chem. Soc., 56, 271-278. (2009).

21. Jawad Y. M., Hamad H. T. and Al-Ragehey A. D. J. M., (2015), J. Coll. Basic Edu., 21, 198204.(2015).

22. Ravisankar P., Navya C. N., Pravallika D. and Sri D. N., JOSRJ. Pharm., 5, 7-19 (2015).

23. British Pharmacopoeia, CD-ROM. London, The Stationery Office Ltd., Norwich NR3 1GN (2013). 